\title{
CORPUS APPROACH TOWARDS NARRATIVE ANALYSIS OF TENSE AND ASPECT
}

\author{
ABORDAGEM DE CORPUS PARA A ANÁLISE \\ DE TEMPO E ASPECTO EM NARRATIVAS
}

\author{
Camila Antônio Barros | Lattes | camila-ab@ufmg.br \\ Universidade Federal de Minas Gerais | Fapemig
}

\begin{abstract}
This research, presented here, centers itself on how both tense and aspect are useful for the narrative analysis. This study presupposes narratives as texts with a temporal elaboration and progression, what demands abilities such as fore- and backgrounding. Such cognitive perspective is expected to dialogue with the Labovian position in the sense that the oppositions of fore- and background may be marked in the verbs. In order to understand how verbal tense and aspect are organized in spontaneous speech narratives in Brazilian Portuguese, the monologues from C-ORAL-BRASIL I minicorpus (RASO; MELLO, 2012) were manually annotated for the verbal categories as well as the Labovian categories (orientation, complication and evaluation). The results point to a tendency that complication will be marked mainly by simple past (pretérito perfeito do indicativo), while evaluation and orientation will be marked by present (presente do indicativo) and imperfective. Lexical aspect has shown an asymmetry between telic and non-telic verbs, and a slightly higher proportion of verbs of accomplishment and achievement in structures of complication.
\end{abstract}

Keywords: Narrative analysis. Foreground/Background. Tense and aspect. Corpus linguistics.

Resumo: A pesquisa aqui apresentada centra-se em como os parâmetros de tempo e aspecto são úteis para a análise da narrativa. Esse estudo pressupõe narrativas como textos com uma elaboração e progressão temporal que demanda as capacidades cognitivas de fore- e backgrounding. Essa perspectiva cognitiva dialoga com a posição laboviana para a análise da narrativa no sentido em que a oposição de Figura e Fundo podem ser marcadas por verbos. Para entender como tempo e aspecto verbais são organizados em narrativas de fala espontânea de português brasileiro, os monólogos do minicorpus C-ORALBRASIL I (RASO; MELLO, 2012) foram anotados quanto a suas categorias verbais e categorias labovianas (orientação, complicação e avaliação). Os resultados apontam para uma tendência em marcar majoritariamente a complicação com o pretérito perfeito do indicativo, enquanto a avaliação e orientação serão marcadas pelo presente do indicativo 
e pelo imperfectivo. $\mathrm{O}$ aspecto lexical mostrou uma assimetria entre télicos e não télicos, e uma maior proporção de verbos de accomplishment e achievement em estruturas de complicação.

Palavras-chave: Análise narrativa. Figura/Fundo. Tempo e aspecto. Linguística de corpus.

\section{INTRODUCTION}

The aim of this paper is to describe which correlations can be stablished between verbal tense and aspect and narrative structures, specially concerning what narrative is in opposition to what supports it. According to Labov and Waletszky (1967) narratives can be defined as a temporal sequence about a series of events that are told in the same order they occur, disregarding time and place of speech (RÜHLEMANN, 2013). Therefore, narratives are set apart from dialogues because they do not update the events online, referring only to past events. Another characteristic of narratives is presenting themselves in monologues, in contexts of low actionality and with an asymmetrical (meaning an unequal) division of turns of speech (if it is inserted in a dialogue).

Those differences can be exemplified by two examples of C-ORAL BRASIL I ${ }^{1}$ (RASO; MELLO, 2012), as shown in the Charts 1 and 2 below. Chart 1 indicates a dialogical situation with a high level of actionality, in which the participants play snooker. Chart 2, on the other hand, illustrates a low situation of actionality, in which the participant MAI monopolizes a turn of speech resulting in a narrative about a man who is eaten by a snake.

Chart 1. Snooker dialog - bfamcv03 [53-58] (cv03_53-58)

\begin{tabular}{llll}
\hline No & Speaker & Utterance & Translation \\
\hline 53 & CEL & e o medo de errar // & 'how about the fear of making mistakes //' \\
54 & CAR & errou / aí // & 'you missed it / see //' \\
55 & REN & confiou / viu // & 'you trusted / see //' \\
56 & CEL & não // & 'no //' \\
57 & REN & cê $<$ erra / nós tava fodido $>/ /$ & 'if you missed it / we would be screwed //' \\
58 & CEL & $<$ agora tem que matar o cinco $>/ /$ & 'now you have to pocket the 5-ball //' \\
\hline
\end{tabular}

The example shown in Chart 1, recorded during a snooker game, has (in Brazilian Portuguese) mainly verbs in the Past simple (pretérito perfeito: errou 'missed', confiou 'trusted') that describe events that are simultaneous to speech and their action ended at the moment they were spoken. They are followed by verbs constrained to the speech 
context, describing what should happen in the following moments of the game.

This shows a verbal progression attached to speech time and its progression follows the actions of the interaction. Chart 2, on the other hand, shows a more 'exosituational' context, in which MAI does not aims to actualize the ongoing moment.

Chart 2. Snake dialog - bfammn01 [34] (mn01-34)

\begin{tabular}{llll}
\hline No & Speaker & Utterance & Translation \\
\hline 34 & MAI & e ea veio / & 'and it came' \\
34 & MAI & ea saiu no $[/ 1]$ & 'it went out in $[/ 1]$ \\
34 & MAI & no $[/ 1]$ & 'in $[/ 1] '$ \\
34 & MAI & no trilho / & 'at the trail' \\
34 & MAI & e rasgou o chapéu todo / 'and tore the whole hat' \\
34 & MAI & nu sendo ele ea $[/ 1]$ & 'and not being him, she [/1]' \\
34 & MAI & ea \&rap $[/ 2]$ & 'she \&rap [/2]' \\
34 & MAI & continuou atrás dele / & 'she continued to chase him' \\
34 & MAI & quebrando // & 'wrecking' \\
\hline
\end{tabular}

Chart 2 shows a different context, in which MAI tells the story of a man who was killed by a snake in front of his family. Those events are unattached to the speech context and are told in the same order that they occurred, therefore this excerpt can be considered a narrative. The separation time and place of the speech is given by the verbs in the past simple, as in Chart 1, but carrying a crucial difference: the action codified by the verb does not end when they were spoken but is constrained to the past. Hence, the tense, alone, does not provide sufficient information to differentiate what is narrative, or is not, bringing up the necessity of also looking for the lexical aspect.

Those insights about tense and aspect that have become relevant to analyze the narrative structure are already present in Hopper and Thompson (1980) studies about transitivity. In this paper, they point out a -ing mark for supporting features of the narratives (background features, according to the author) in opposition to other tense marks which are more typical of a narrative. In the examples above, it is shown that in Brazilian Portuguese there is a correspondence: the online actualizations of the dialogue do not have a verbal mark, while -ing would only appear in the narrative to describe continuous actions that not necessarily compound the narrative track, but provide a support to the listener understanding of it, e.g. "wrecking” (quebrando).

Such research is justified by using spontaneous speech data for narrative studies, looking for a new perspective beyond literary contexts (FLEISCHMAN, 1990; 
TURNER, 1996) and interviews (AZEVEDO, 2005; LABOV; WALETZKY, 1967). The methodology takes as data the monologues of the C-ORAL-BRASIL I minicorpus (RASO; MELLO, 2012).

The analysis enables us to conclude that in Brazilian Portuguese (in the variety of the State of Minas Gerais, which is the scope of the corpus) there is a tendency for the past form of the verb with a continuous aspect (imperfect), regarding the parts that are dedicated to orientate the listener towards the narrative. Besides, lexical aspect is relatively proportional within the monologues, but the aspects of accomplishment and achievement are proportionally (considering lemmas) more frequent in complication parts.

\section{THEORETICAL REVIEW}

\subsection{The Labovian Approach in contrast to the cognitive approach}

Narratives can be defined, according to Labov and Waletzky (1967), as a sequence of events told in the same order as they occurred. This order is given by the verbal temporal progression, which organizes the events through a temporal juncture and ties narrative elements with the same time notion that is effective (or true) throughout the narrative. Such organization does not allow a narrative clause to be moved without entailing a different interpretation. The temporal progression is not necessarily given by verbs only. However, only this kind of mark was considered in this work.

Another important feature is the qualitative division of narrative components, namely "orientation", "complication" and "evaluation". The first category, orientation, holds the main narrative components "who?”, “when?", “where?” and "how?". Complication is the core of the story followed by evaluation, category that justifies why the narrative is worth being told. The authors also name "resolution", "coda" in the end (1967) and possibly an "abstract" (LABOV, 1997), but those categories are not so specific and also not so fundamental to the narrative structure. The decision to exclude "resolution" was grounded on its similarity to the broader category of "evaluation", being both hard to distinguish one from another (LABOV; WALETZKY, 1967). Therefore, we chose only to annotate the broadest category. We have considered the "coda" category only in cases of interruption in the narrative flow and when there was a switch from monologue to dialogue in the spoken text.

On one hand, the fruitful study of Labov about the matter is a continuity to the (pre-) structuralism in literature (BARTHES, 1971; PROPP, 1968) analyzing how different storylines are organized. On the other hand, the Labovian Approach breaks with the tradition of a purely structural analysis of the narrative, which used only textual pa- 
rameters, to include pragmatical and interactional parameters. This can be attested by the evaluative part, which allows the speaker to validate the narrative as well as connect the effort that the speaker must maintain his/her turn to the emotional connection towards the story being told.

Narratives can also be seen from a different (more abstract) perspective, in which they are a manifestation of thought. This step back can be small, as debated by Edwards (1997), treating narratives as a discursive phenomenon, or big as taken by Wallace Chafe (1990) and Mark Turner (1996) who treat narratives as a basic manifestation of thought. Chafe argues that narratives combine a sensorial experience with the ability of communicate something creatively; therefore, they are the first product after an organizational process within thought about a given event.

This treatment of the narrative can be expanded to linguistic matters for there are associations of the cognitive functions of the human brain and the speech production. To Chafe (1990, p. 80), this works through a wider formation of meaning, in which the sensorial experience is guided and constrained by personal expectations (both speaker and listener) as well as by empirically formed schemes. Langacker (1987) understands meaning (in more technical terms) as the result of the junction of a conceptual content, a neutral manner to evocate an object in the world, and a construal content, the ability to conceive and represent the same situation in different manners. In a narrative, this can be seen as a conciliation of the cultural and cognitive functions that operate in the linearization of experience using pre-established structures. Turner (1996) sees such conciliation as a product of spatial and imagetical schemes with Figure and Ground categories. Hence, the information given by the senses are assorted in a more (Figure) or less salient (Ground) categories. For narratives, all those manners of organizing the thought own a common denominator: guiding what can be done in the grey area between sensorial experience and linguistic output.

According to a series of studies (AZEVEDO, 2005; BOGDAN; SULLIVAN, 2011; CUTRER, 1994; FLEISCHMAN, 1990; LÓPEZ-ORTEGA, 2000; SILVACORVALÁN, 1983; SULLIVAN; BOGDAN, 2001)an issue that has attracted recent controversy (Wolfson 1979, Schiffrin 1981, verbs have a very important role in organizing the narrative experience because they mark the temporal concatenation of this kind of discourse. Therefore, it makes sense combine the verb-guided Labovian Analysis to a cognitive approach that searches for different instances in a text: a difference in what structure is more salient in opposition to what is not. Another argument for such com- 
bined approach is that in both perspectives there is an asymmetry between what is narrative (Figure, complication) and what supports the narrative (Ground, orientation and evaluation) (HOPPER; THOMPSON, 1980).

\subsection{Tense and aspect in Brazilian Portuguese}

To understand how different verbs can codify an asymmetrical structure within the narrative, the way verbs work in each language must be understood too. In this case, how Brazilian Portuguese verbs work. In this language, verbs are a predicative structure that marks person, number, tense, mode, and aspect. We will emphasize ${ }^{2}$ tense and aspect only in Brazilian Portuguese, which are crucial to this paper.

Tense is a deictic category that identifies what is said (A) in relation to when it is said (B), indicating "the time when an action or event occurs or when a state or process holds" (HAMM; BOTT, 2018, p. 1). As in English, there are three possibilities: A precedes $\mathrm{B} \rightarrow$ past, $\mathrm{A}$ and $\mathrm{B}$ are simultaneous $\rightarrow$ present, and $\mathrm{A}$ comes after $\mathrm{B} \rightarrow$ future. Those marks occur paradigmatically using suffixes that may be applied to either the auxiliary verb or the full verb. They are also merged with mode categories.

\section{Example 1. Tense in Brazilian Portuguese}
a) $\mathrm{Eu}$ corri.
I ran.
b) Eu corro.
Irun.
c) $\mathrm{Eu}$ correrei.
I will run.

All the examples in 1 are from the indicative mode, in its simplest form (synthetical form). Indicative past is also codified by compound perfect (eu tinha corrido), an imperfect form (synthetical: eu corria; compound: eu estava correndo) and a past perfect form (eu correra - rarely used). A similar variety of forms also is possible for indicative future, which is also codified by a compound form (eu vou correr) and a conditional future (synthetical: eu correria; compound: eu teria corrido). Tense and mode in opposition to aspect are inherent to verbal paradigm in Brazilian Portuguese. The conditional and imperative

\footnotetext{
2 This analysis is by no means exhaustive, leaving a lot on the side for the specific purposes of this study. For more extended analysis, Castilho (2010), Cançado and Amaral (2016) among many others are more adequate.
} 
modes do not codify grammatical aspect, thus they were not considered in the analysis (TRAVAGLIA, 1981). Aspect describes a temporal notion as well, but it differs itself from tense because it is not a deictic category. As Comrie (1976, p. 3 ) defined, "aspects are different ways of viewing the internal temporal constituency of a situation”. It can be divided in three axes: a) syntactical-semantical, b) lexical-semantical and c) discursive. The first one refers to the grammatical codification of the temporal development in the verbal morphology; b) refers to the degree of development of a given verbal action/ event/process/state inherent to the verbal root and c) how the verb may form the Figure and Ground distinction in a text (CASTILHO, 2010).

In the syntactical-semantic interface, grammatical aspect may have a considerably varied classification but, regardless of the reference, there is a common denominator for the categories of perfective and imperfective. The first describes an action as a single whole, while the second describes an unfinished action, paying "attention to the internal structure of the situation" (COMRIE, 1976, p. 16). These definitions were considered in a robust classification for Brazilian Portuguese, for instance, Travaglia (1981), as well as Castilho (2010) and Cançado and Amaral (2016) that used slightly different classifications for describing the interaction of grammatical aspect with tense and lexical aspect.

Lexical aspect, on the other hand, refers to verbal classes that have different time circumscriptions. An easy example for it is the difference between a) I run and b) I know, in a) it is understood as progressive action without an established end (one may run a mile or 300 miles and still have run), thus is an activity, while b) entails a verb of achievement, that is to say, there is a point that has to be achieved in order to know something (one knows how to ride a bike or one does not know, there is no in-between). According to Vendler (1957), we can distinguish four categories of lexical aspect, activities, accomplishments, achievements and states with the parameters of telicity, dynamicity and punctuality. Telicity meaning there is an established point of an end, dynamicity refers to the event whether it requires any force to happen and punctuality refers to eventualities that are constrained to a unique and instantaneous moment. Cançado and Amaral (2016, p. 161-166) propose that punctuality is not enough to describe achievement verbs, which is better understood by intervals: achievements do not have intervals within its events, while state, activity and accomplishment verbs do. Those parameters are comply to the restriction imposed by the arguments, such is the case for an activity verb as run, that can be derived to an accomplishment by the argument 100 miles, setting a goal. In this paper we only considered basic aspects. 
Chart 3. Lexical aspect classifications, adapted from Cançado and Amaral (2016)

\begin{tabular}{lcccl}
\hline Class & Dinamicity & Intervals & Telicity & Test \\
\hline State & - & + & - & *What happened? \\
Activity & + & + & - & Imperfective paradox \\
Accomplishment & + & + & + & nearly ambiquity \\
Achievement & + & - & + & stop agrammaticality \\
\hline
\end{tabular}

In Chart 3 we have a summary of the classification of Vendler's aspectual classes, in the parameters of dynamicity, intervals and telicity. State verbs are not dynamic but have intervals, activity verbs also have intervals, but are dynamic and both are not telic. Accomplishment and achievement verbs are telic and dynamic, but achievement verbs do not entail intervals while accomplishment verbs do. In the last column, there is a short description of the tests that can be made to distinguish the verbs, as Cançado and Amaral's review from Dowty (1979). A state verb can be distinguished because it does not answer to the question What happened? (it is ungrammatical to answer such a question with "I have a beach house"). An activity verb entails the imperfective paradox, that is, when one starts an activity, one has also ended it (I was drinking water $\rightarrow$ I drank water). Accomplishment verbs are ambiguous in sentences with nearly, because on one reading one has not started the action or on another reading one has not finished the action (I nearly built a sandcastle). Achievement verbs cannot be stopped, that is e.g. one cannot stop to arrive, that is, an achievement has a settled end and if it is interrupted, it is not completed.

For Brazilian Portuguese, there is a sort of agreement among different authors that have considered both sorts of aspects in their verbal classification. Associating those aspects with the perspective of Hopper and Thompson (1980) and Labov and Waletzky (1967), it is possible to distinguish that narrative excerpts (Figure and complication) are marked with past verbs in perfective form presumably with accomplishment and achievement verbs. The parts that are not explicitly narrative and serve to support the understanding of the listener (Ground, orientation and evaluation) will carry the marks of varied verbal tenses and aspects. This was already stated by Azevedo (2005) for Brazilian Portuguese, except for the hypothesis for the lexical aspects.

Another further contribution of this paper is the corpus data of spontaneous speech by using the monologues of C-ORAL BRASIL I (RASO; MELLO, 2012). Even though narrative is treated as an universal form of speech and discourse, it is mainly studied in controlled contexts, such as literary texts and interviews, being Rühlemann (2013) an ex- 
ception that worked with a quantitative approach of narratives in corpora. The same may be applied to studies about verbs in Brazilian Portuguese that have not considered the contributions that a corpus-based study may bring to descriptions, especially in speech form. Castilho (2010), e.g., uses the NURC corpus (CASTILHO, 1990) without systematically deriving his descriptions from it.

The next section will explain the C-ORAL-BRASIL I architecture and the methodological decisions that were taken by this work.

\section{METHODOLOGY}

The aim of this work is to analyze monologues containing narratives through a qualitative and quantitative perspective about the variables of time, aspect and narrative structure. The monologues were taken from the minicorpus of C-ORAL-BRASIL I corpus (RASO; MELLO, 2012), a reference corpus of spontaneous speech for the Brazilian Portuguese dialect spoken in the state of Minas Gerais. The monologues are compound by seven texts that sum up to $\sim 10000$ words and 1 h05' 40 " of audio.

The C-ORAL-BRASIL I corpus is a part of the C-ORAL family (CRESTI; MONEGLIA, 2005), a corpora collection of Italian, French, Spanish, European Portuguese and Brazilian Portuguese, that is be actionally representative, containing as many different communicative situations as possible. The C-ORAL family has a structure that fits a specific theoretical framework, the Language into Act Theory (CRESTI, 2000). For our purposes, it is only crucial that we understand how the theoretical framework inflected the transcriptions and compilation of the corpus, especially concerning prosodic segmentations and annotations. The utterances are segmented by their autonomy, that is an utterance is a pragmatic and prosodic autonomous unit, that may be composed by a non-terminal sequence, the tonal units, in opposition to a syntactically driven segmentation.

A monologue is defined here as the result of a representative linguistic production of a single participant (adapted and translated, MITTMANN, 2013, p. 341), in opposition to dialogues, relatively balanced productions of two speakers, and conversations, communicative situations of more than two participants. In this work, we analyzed the seven monologues in the minicorpus, all of them, containing narratives. The narrative content of the monologues bfammn06 and bpubmn01 (Chart 4) is debatable, due to the fact that they portrait an "interview-like" situation rather than a narrative, but they were kept for they can be understood as a narrative in the sense that it describes the relation 
between the speaker and his/hers career path.

Chart 4. Minicorpus metadata of C-ORAL-BRASIL I

(adapted from MITTMANN; RASO, 2011)

\begin{tabular}{cc}
\hline File & Interaction \\
\hline bfammn01 & Man tells an alleged true story about a snake \\
bfammn02 & Grandmother tells grandson stories about her famous uncle \\
bfammn03 & Father tells family two entertaining stories \\
bfammn04 & Woman tells about her experience in the hospital \\
bfammn05 & Woman shares the story about her daughter's adoption \\
bfammn06 & Man explains its professional trajectory \\
bpubmn01 & Teacher evaluates her work at public school \\
\hline
\end{tabular}

The C-ORAL BRASIL has multiple versions available, from a plain .txt text through an.$x m l$ version of Speech-to-text alignment, passing by an informational structure annotation in the minicorpus and a parsed version in.$x m l$ format. The ideal one for this paper would be the parsed version, for it would spare time of the manual annotation. However, this would come with two main problems, first the chance of error that is inherent to automatic annotations ${ }^{3}$ and, secondly, the retrieving of the annotated data which was beyond the author's current computational abilities. Therefore, it was used the annotated version with information structures of the minicorpus available at the DB-IPIC ${ }^{4}$ platform. The downloaded .csv files were converted to spreadsheets. The utterances were organized in tonal units, because in most cases there was only one verb for each tonal unit. As any other spoken corpora, the monologues had also utterances that were empty, that is, utterances that had retracting (hesitations) and other speech phenomena that do not use a verb. Therefore, they were not considered in the counting. To support this with numbers: of the 3353 tonal units in the monologues, only 1432 of them had a verb that was not retracting or an empty information structure and were annotated.

Out of the 1432 tonal units that had verbs, each one of the 1661 verbs were annotated. Only one token was counted in verbal periphrases, following Castilho (2010, p. 393-394). For the grammatical aspect classification, it was considered that gerund forms (gerúndio, the equivalent to -ing termination in English), imperfect past (pretérito imper-

${ }^{3}$ Even though the parser PALAVRAS (BICK, 2000) has a 93.7\% precision rate for the syntactic annotation (BICK, 2013) no specific test was made regarding the verbal aspect and time specifically within the framework used.

${ }^{4}$ DB-IPIC <http://www.lablita.it/app/dbipic/> is a platform that some corpora of the C-ORAL Family are made available, allowing the user to look for the texts, information units as well access the audios, download them and export the transcriptions. 
feito), irrealis periphrastical future (futuro do pretérito do indicativo) and present in atelic verbs were imperfect. On the other hand, present in telic verbs, periphrastical future of $r e-$ alis mode, simple past (pretérito perfeito) and participle are perfective. Subjunctive, imperative and infinitive do not have grammatical aspect (TRAVAGLIA, 1981). Periphrastic future (futuro do pretérito) was considered as imperfective, according to Fonseca (2010) aspectuals and modal values were updated. We believe that the multifunctionality of this construction is a consequence of varying degrees of grammaticality in this verbal group and its types are updated following the universal grammaticalization order of inflectional verbal categories (BYBEE, 1985, which pointed out that the auxiliary verb codifies imperfect aspect even though the main verb does not.

The lexical aspect was then annotated according to Cançado, Amaral and Meirelles (2017), applying in the tests presented in Table 3. As the tests were made for non-speech data, they had to be adapted to what was presented by the data. Finally, Labov and Waletzky (1967) categories of narratives structure were annotated. Orientation, complication and evaluation were defined considering mainly the locutive content and the position of the tonal unit within the narrative (OUYANG; MCKEOWN, 2014). In Chart 5 , an example is presented of the classification of the narrative bfammn01, in which the narrator tells how an acquainted was attacked by a snake.

Chart 5. Examples for narrative structures

\begin{tabular}{|c|c|c|}
\hline $\begin{array}{l}\text { Narrative } \\
\text { structure }\end{array}$ & Definition & Example \\
\hline \multirow{2}{*}{ Orientation } & \multirow{2}{*}{$\begin{array}{l}\text { Tells the wh-questions } \\
\text { about the narrative }\end{array}$} & $\begin{array}{l}\text { MAI: }[18] \text { e aí / segundo o [/1] o parente dele que } \\
\text { é mais chegado / contou pra nós o seguinte pra } \\
\text { mim // }\end{array}$ \\
\hline & & $\begin{array}{l}\text { en. 'and then / according to }[/ 1] \text { to his relative that } \\
\text { is more acquainted [to the dead man] / told me this } \\
\text { //, }\end{array}$ \\
\hline \multirow{2}{*}{ Complication } & \multirow{2}{*}{$\begin{array}{l}\text { Narrative theme/main } \\
\text { subject }\end{array}$} & MAI: [59] aí matou ele // \\
\hline & & en. 'then [the snake] killed him //' \\
\hline \multirow{2}{*}{ Evaluation } & \multirow{2}{*}{$\begin{array}{l}\text { Narrator/Speaker } \\
\text { perspective about the } \\
\text { related events }\end{array}$} & $\begin{array}{l}\text { MAI: [68] nũ sei / né / a imaginação hhh dum [/1] } \\
\text { dum animal / o que que pode ser / né // }\end{array}$ \\
\hline & & $\begin{array}{l}\text { en. 'I don't know / right / his imagination hhh of } \\
\text { [/1] of an animal / what it may be / right //' }\end{array}$ \\
\hline
\end{tabular}

Chart 5 shows an example for each narrative structure, taken from bfammn01, the audio file that tells an alleged true story about a man who is killed by a snake. Orientation structure tells the circumstances in which the narrative happened; therefore, the example tells the relation of MAI to the story that he is about to tell. Complication is the core 
of the narrative, its more fundamental content, therefore is exemplified by the utterance "then [the snake] killed him //". And finally, evaluation structure is MAI's perspective about what could the snake have thought about the episode narrated, "I don't know / right / his imagination hhh of [/1] of an animal / what it may be / right //". According to the transcripts conventions (RASO; MELLO, 2012), "hhh" indicates a paralinguistic sound.

\section{DATA ANALYSIS}

The study begins by a qualitative analysis and is followed by the quantitative analysis of the data. This allows us to analyze how the monologues work as narratives within the corpus and then look for how they are quantitatively organized by its verbs.

\subsection{Qualitative analysis}

In this analysis, we observed how orientation, complication and evaluation are units distributed among the different files in the minicorpus. Those are more canonical structures that are built in an orientation, complication, and evaluation. However, there are also files (bfammn04 and bfammn05) that the evaluation and complication structures can be confounded and there are monologues that the evaluation structures appear throughout the whole text. In two files we have more than one narrative: bfammn02 has three separate narratives and bfammn03 has two narratives.

In bfammn01 there is only one narrative, in which MAI tells about a friend of the family that was killed by a snake bigger than an anaconda that crackled (canta igual galo, en. "sings like a hen"). It is composed by 33 units of orientation, 78 of complication and 13 evaluation points, distributed one after the other. The orientation starts with MAI describing how he is related to the story (it is about a relative of his wife) and that there is a huge snake in the countryside where this relative lived. He continues with the complication part, in which the wife's relative goes to the city to buy something for the household and then is attacked by the snake. Among those 78 tonal units of complication, there are two units of orientation: MAI establishes a parallel between how the countryside in the city of Belo Horizonte is, where the interaction takes place, and the countryside where the story takes place. Doing this, he manages to establish two different places setting apart where they (MAI and DUD) are and where the narrative takes place. The structure of the evaluation is compound by 13 tonal units, in which MAI imagine what could have passed in the thoughts of the animal, the snake, before killing the man and ends the story in an uncompromised way saying that he only heard the narrative (but he does not admit its doubtful tone). In the end of the monologue, a dialogue takes place and DUD starts to doubt about the veracity of the story, but they do not reach a consensus. 
The niece (DFL) of a Brazilian poet, who tells about her relationship with her uncle, is in the second file, bfammn02. The file can be fragmented in three different stories. The first about her nephew "Laurinho" that liked to boast about a famous uncle. Secondly, she tells how her doctor reacted when he discovered about her family and at last, she narrates how the relationship between her father and uncle was. All the three narrative cores are well fitted to the structure predicted by Labov and Waletzky (1967), starting with orientation, followed by complication and ending with evaluation. This is clearer in the Figure 1 , in which it is possible to see three different nuclei.

The file bfammn03 is composed by two narratives told by ALO: a widow that offended her late husband and how the children of a late client paid her debts years after her death. The first one (and odder one), has more evaluation sequences (16 of them) while the second one has none. Both sum up 26 units of orientation and 172 tonal units of complication.

Both bfammn04 and bfammn05 have a similar content in the sense that they are mothers narrating about their children. This closer and more affective relationship throughout the narrative is marked by an extended evaluation structure. Bfammn04 starts an orientation, in which REG is highly emotionally involved, telling about how she gave birth in a car. Here we have 44 evaluation tonal units intercrossed with complication units, indicating that REG constantly comments her impressions about what happened while telling it. In the other file, bfammn05, the narrator tells how she lost her daughter and decided to adopt another. In this file, there are 24 units of orientation, 203 units of complication and 42 units of evaluation. There are nine units that are an interruption of the recording. They were not considered in the quantitative analysis.

The last two files can be considered more like interviews than narratives, merging complication and evaluation. This is because both are narratives of professional experience, in which past facts are correlated to the current working field. In bfammn06, there are 14 units of orientation, 112 complication units and 84 units of evaluation. Bpubmn01 has 40 units of orientation, 141 complication units and 94 evaluation units.

The distribution of the narrative structures within the narratives can be better seen in the Figure 1, made with the software Orange (DEMŠAR et al., 2013): 
Figure 1. Distribution of the narrative structures

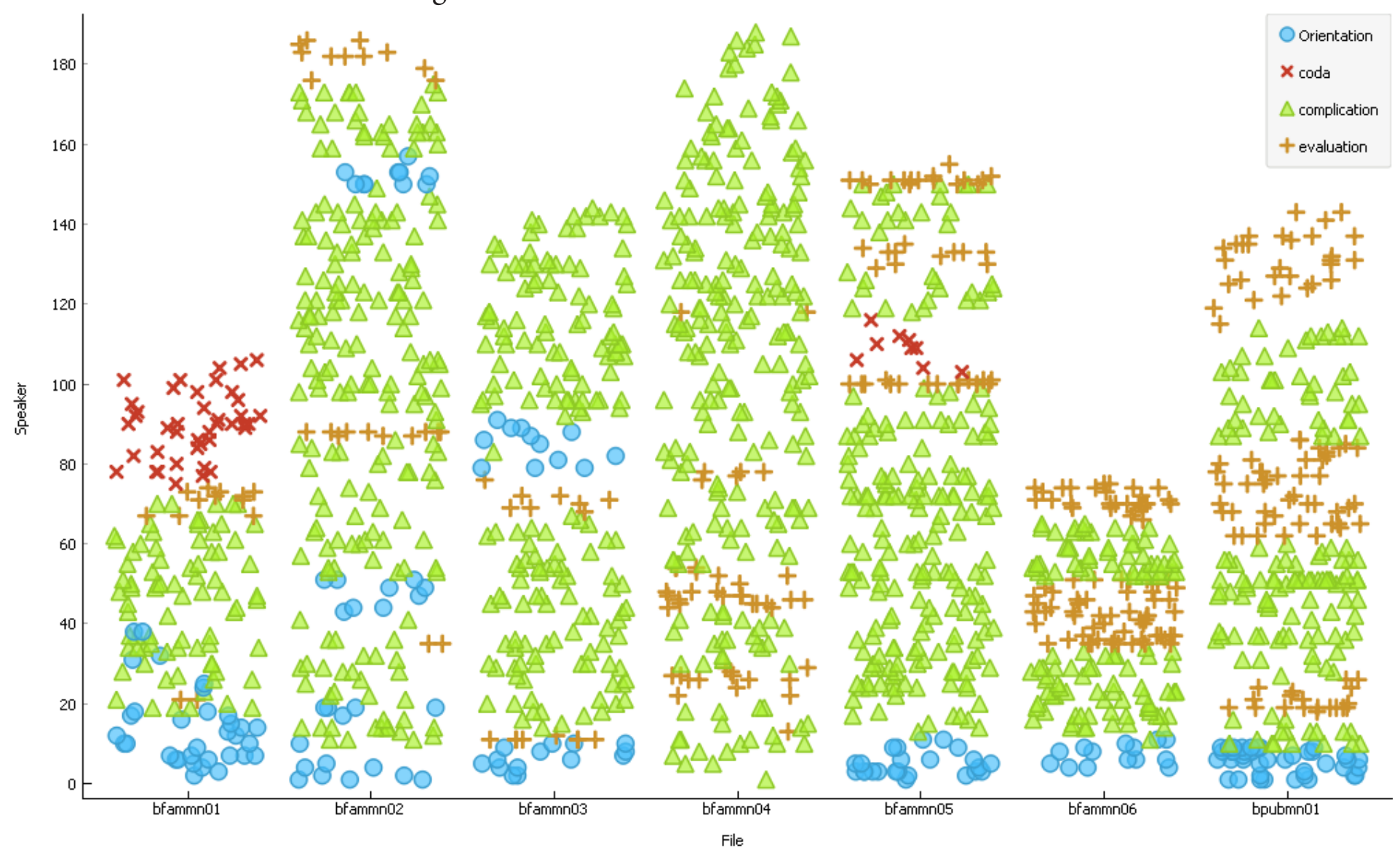

On the $\mathrm{x}$-axis are disposed the files names and on the $\mathrm{y}$-axis are disposed the utterances numbers, being each tonal unit plotted in the same $\mathrm{x}$-axis level. Each column indicates a specific file, which allows an easier visualization of the descriptions in this section: structures of orientation starting narratives (blue), complication units throughout the text (green), and evaluation units ending or among complication units (orange) and coda units (red) maintained to show interruptions and displacement of the narrative context. Orientation is related mainly to beginnings, therefore shows up more times in bfammn02 and bfammn03. Narratives with higher emotional appeal such bfammn04 and bfammn05 as well as the ones with a more professional content - bfammn06 and bpubmn01 - have more evaluation units. The coda units serve (here) to show dialogues excerpts within the monologues.

Here, the Labovian analysis raises two main tracks in the narrative similar to the cognitive approaches of Figure and Ground: the complication is the bulk of the story being told and has a more salient content, while orientation and evaluation set the scene to the narrative, grounding it. 


\subsection{Quantitative analysis}

As previously pointed out, the total data analyzed sums up to 1661 verbal occurrences (taken from 999 utterances and 3352 tonal units), the non-verbal utterances and retracting were deleted from the analysis. There are 266 individual verbs (types). From those verbs were also discarded those which mark synthetically future (futuro do indicativo sintético) subjunctive and imperative mode and infinitives that do not codify grammatical aspect. In 1450 occurrences there are still 50 coda units. Therefore, the fine-grain analysis was only made in 1400 tonal units that contained verbs that codified tense, grammatical, and lexical aspect and were a part of the narrative structures of orientation, complication, and evaluation.

In order to summarize the data analysis, all possible forms of a given tense were added under the same label: e.g., under "Past" in Table 1 there are both perfect and imperfect forms of the indicative in the synthetical and periphrastic forms. The same holds for the other tense labels ("Future", "Present", "Continuous", and "Participle"). In a different column the grammatical aspect was annotated with the labels "perfect" or "imperfect". Lexical aspect and Narrative Structure were then annotated. A sample chart of this annotation is on the Chart 6, below $^{5,6}$.

Chart 6. Sample of analysis

\begin{tabular}{|c|c|c|c|c|c|c|}
\hline No & Speaker & Utterance & Tense & G.A. & L. A. & Narrative \\
\hline 49 & DFL & parece que começou assim // & PRS & IPFV & state & \multirow{4}{*}{ Orientation } \\
\hline 49 & DFL & parece que começou assim // & PST & PFV & achievement & \\
\hline 51 & DFL & papai foi o irmão que mais deu $[/ 1]$ & PST & PFV & state & \\
\hline 51 & DFL & deu apoio a ele // & PST & PFV & accomplishment & \\
\hline 53 & DFL & era de uma família abastada / & PST & PFV & state & \multirow{3}{*}{ Complication } \\
\hline 53 & DFL & porque o professor ia em casa / & PST & IPFV & accomplishment & \\
\hline 53 & $\overline{\mathrm{DFL}}$ & nu ia po grupo não // & PST & IPFV & accomplishment & \\
\hline
\end{tabular}

Those 1.400 occurrences were divided in 154 orientation units, 987 complication units, and 259 evaluation units. This corroborates the analysis of Labov and Waletzky (1967) as well as the analysis of Ouyang and McKeown (2014) in terms of distribution and absolute numbers. This distribution is justified by complication being the most important part of the narrative, followed by the evaluation, for it is what validates what is told, and orientation has fewer units, because it is more punctual. 
Table 1. Tense and Narrative's structures correlations

\begin{tabular}{lcc|cc|cc|c}
\hline & \multicolumn{2}{c}{ Orientation } & \multicolumn{2}{c}{ Complication } & \multicolumn{2}{c}{ Evaluation } & Total \\
\hline Present & 70 & $45,5 \%$ & 361 & $36,6 \%$ & 149 & $57,5 \%$ & 580 \\
Past & 62 & $40,3 \%$ & 525 & $53,2 \%$ & 82 & $31,7 \%$ & 669 \\
Future & 4 & $2,6 \%$ & 25 & $2,5 \%$ & 5 & $1,9 \%$ & 34 \\
Continuous & 15 & $9,7 \%$ & 58 & $5,9 \%$ & 22 & $8,5 \%$ & 95 \\
Participle & 3 & $1,9 \%$ & 18 & $1,8 \%$ & 1 & $0,4 \%$ & 22 \\
\hline & 154 & $100 \%$ & 987 & $100 \%$ & 259 & $100 \%$ & 1400
\end{tabular}

First, we should analyze how the narrative structures correlate with tense (Table 1). There is the prevalence $(\mathrm{p}<.05)^{7}$ of orientation $(45,5 \%)$ and evaluation $(57,5 \%)$ to be marked by present (presente). Orientation was also marked with past (pretérito) almost the same as present, but with some slightly lower figures. Complication as the opposite pattern: $53,2 \%$ of its units are marked with past (pretérito).

Table 2. Grammatical aspect and Narrative's structures correlations

\begin{tabular}{lcc|cc|cc|c}
\hline & \multicolumn{2}{c}{ Orientation } & \multicolumn{2}{c}{ Complication } & \multicolumn{2}{c}{ Evaluation } & Total \\
\hline Perfect & 62 & $40 \%$ & 533 & $54 \%$ & 84 & $32 \%$ & 679 \\
Imperfect & 92 & $60 \%$ & 454 & $46 \%$ & 175 & $68 \%$ & 721 \\
\hline & 154 & $100 \%$ & 987 & $100 \%$ & 259 & $100 \%$ & 1400
\end{tabular}

On Table 2 we see a second analysis, correlating grammatical aspect and narratives structures. We can see here that numbers are not as informative as expected. First, complication has much more occurrences than orientation and evaluation. There is a slightly higher use of perfect in the first category than the other two, which is more salient in correlation to past and perfect: in the 70 occurrences of present of orientation, 60 of them are imperfective; in the evaluation, the pattern is the same - out of 149 occurrences of present, 123 of them are imperfective; in the complication, there is a more balanced division between perfect and imperfect. However, those tendencies are too weak to be considered relevant without a further statistical treatment.

Lexical aspect, on the other hand, is more homogeneously distributed than tense and grammatical aspect, what does not allow us to extract a pattern for narratives in absolute values even though the results are significant $(\mathrm{p}<.05)$, showing that verbs of

\footnotetext{
${ }^{7}$ All Chi-square tests were made in the platform http://turner.faculty.swau.edu/mathematics/math241/ materials/contablecalc/.
} 
accomplishment and activity are more balanced than the achievement and state verbs. However, this significance is biased for state verbs such as ser and estar (different senses of the English verb to be) are highly frequent in the whole corpus (RASO; MELLO, 2012, p. 275-278), what bias the analysis. We could not find a quantitative analysis of the proportions of lexical aspect in Brazilian Portuguese, what would allow us to compare is that narratives have a special pattern.

Table 3. Lexical aspect and narrative's structures correlations

\begin{tabular}{lcc|cc|cc|cc}
\hline & \multicolumn{2}{c}{ Orientation } & \multicolumn{2}{c}{ Complication } & \multicolumn{2}{c}{ Evaluation } & \multicolumn{2}{c}{ Total } \\
\hline State & 68 & $44 \%$ & 316 & $32 \%$ & 135 & $52 \%$ & 519 & $37 \%$ \\
Activity & 34 & $22 \%$ & 280 & $28 \%$ & 57 & $22 \%$ & 371 & $27 \%$ \\
Accomplishment & 40 & $26 \%$ & 277 & $28 \%$ & 51 & $20 \%$ & 368 & $26 \%$ \\
Achievement & 12 & $8 \%$ & 114 & $12 \%$ & 16 & $6 \%$ & 142 & $10 \%$ \\
\hline & 154 & $100 \%$ & 987 & $100 \%$ & 259 & $100 \%$ & 1400 & $100 \%$
\end{tabular}

In order to avoid the bias of high frequency state verbs, we may look at the relative frequencies of the lemmas. According to what was analyzed by Hopper and Thompson (1980), achievement and accomplishment verbs should compose most of the complication structure since they are telics (in the author's words, narratives are marked by completed actions). The data from this compilation argues towards this distinction, when the relative frequencies of the lexical aspect are observed in relation to the narrative structure.

Figure 2. Relative frequencies on narrative structures and lexical aspect

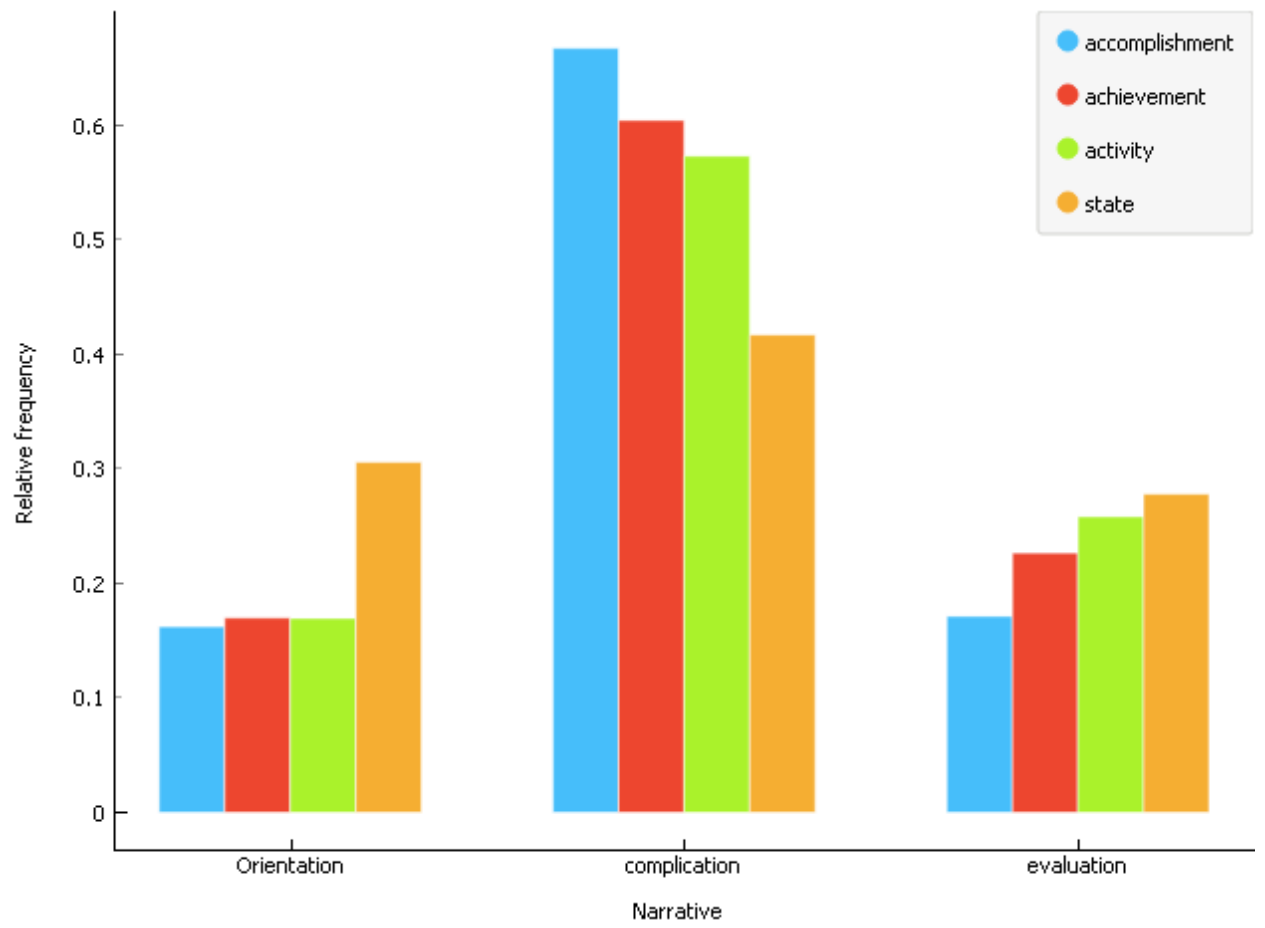


On Figure 2 we may observe that the complication structure is mainly marked by accomplishment and achievement verbs, considering lemmas individual occurrences in opposition to activities and state verbs. The pattern is reversed in the supporting structures.

However, we must emphasize the fact that those frequencies are only slightly different from each other. The distinction between state and non-state verbs is more relevant to establish a narrative and non-narrative plane: $63 \%$ of them are marked with present tense, while non-state verbs are mainly marked with past tense (53\% of the activity verbs, $54 \%$ of the accomplishment verbs and $67 \%$ of the achievement verbs).

\section{DISCUSSION AND CONCLUSION}

The presented data corroborates to observe that there are different ways to mark narrative beyond its locutive content, which resides besides the storyline itself, creating a context with the narrative on the past as a complication and another with present marks that orientates and evaluates the narrative. Such claims were already made for different sets of data and languages, but a similar cognitive process that guides the organization of the narrative can explain what they sustain for written and spoken as well to elicited and spontaneous data.

On the Labovian perspective, the cognitive background was not set yet, but the relations established between past simple and present as the kern of the narrative in opposition to "free-clauses" that mark orientation structures gave a starting point for analyzing narratives in a broader way. Hopper and Thompson (1980) generalized those assumptions for other languages, proposing that there is a foreground and a background opposition in the narrative, the first is the marked with the perfective aspect while the second supports the narrative, providing important information for the listener, more diversified in terms of tense and aspect. This was observed by Azevedo (2005) in elicited narratives in Brazilian Portuguese.

In this paper, those observations were taken to a corpus analysis, what has shown that past is the main mark for complication structure, that the narrative part, while in the present and nominal forms, are more used for background structures. Specifically, the orientation is more homogeneous towards this parameter because it builds a bridge between the moments that the narrative is told and when it happened. Complication or foreground structures are not categorically defined, since the difference between perfect and imperfect aspects is not as big as orientation and evaluation. Still, those verbs in the 
past are mostly perfects, as shown by Azevedo (2005). Hopper and Thompson's (1980) claims for the lexical aspect are correct but were not entirely sustained, since the asymmetry between telic and non-telic verbs within the narrative must be compared to non-narrative texts. It can only form a dichotomy between state and non-state verbs, in which the first category is supporting the narrative and the second category compounding the narrative.

Hence, telic verbs marked with perfect and in the past have a tendency to be used to mark foreground while non-telic verbs marked with imperfective and in the present are more commonly used to mark background.

\section{References}

AZEVEDO, A. M. T. DE. Domínios discursivos: uma visão cognitiva da estruturação de narrativas orais. 2005. 243f. Tese (Doutorado em Linguística) - Faculdade de Letras, Universidade Federal de Minas Gerais, Belo Horizonte, 2005.

BARTHES, R. Análise estrutural da narrativa: pesquisas semiológicas. Tradução Maria Zelia Barbosa Pinto. Petrópolis: Vozes, 1971.

BICK, E. Parsing Speech Data: The Automatic Grammatical Annotation of the C-ORALBrasil Corpus. Proceedings of GSCP 2012, Belo Horizonte, p. 27-32, 2013. Disponível em: http://digital.casalini.it/9788866553519.

BICK, E. The parsing system palavras - automatic grammatical analysis of portuguese in a constraint grammar framework. 2000. 505 f. Aarhus University Press, 2000. Disponível em: http://www.lavoisier.fr/notice/frYWOOR6SAS3WLLS.html.

BOGDAN, D. R.; SULLIVAN, W. J. Polish tense and aspect in narrative context: an analysis of written text. Tampa Papers in Linguistics, v. 4, n. 2, p. 35-46, 2011. Disponível em: https://journals.flvc.org/floridalinguisticspapers/issue/view/4442.

CANÇADO, M.; AMARAL, L. L. Introdução à semântica lexical: papéis temáticos, aspecto lexical e decomposição de predicados. Petrópolis: Editora Vozes, 2016.

CANÇADO, M.; AMARAL, L.; MEIRELLES, L. VerboWeb - syntactic-semantic classification of Brazilian Portuguese verbs - Faculdade de Letras. 2017. Disponível em: http://www.letras.ufmg.br/verboweb/. Acesso em: 31 jul. 2019.

CASTILHO, A. T. DE. Gramática do português falado. Campinas: Unicamp/Fapesp, 1990.

CASTILHO, A. T. DE. Nova gramática do português brasileiro. 1. ed. [S.l.]: Editora Contexto, 2010.

CHAFE, W. Somethings that narratives tell us about the mind. In: BRITTON, B. K.; PELLEGRINI, A. D. (Org.). Narrative thought and narrative language. Hillsdale, New Jersey: Lawrence Erlbaum Associates, 1990. p. 79-98. 
COMRIE, B. Aspect. Cambridge: Cambridge University Press, 1976.

CRESTI, E. Corpus di Italiano parlato. Firenze: Academia della Crusca, 2000. v. 1.

CRESTI, E.; MONEGLIA, M. The C-ORAL-ROM Integrated Reference Corpora for Spoken Romance Languages. Amsterdam/Philadelphia: John Benjamins Publishing Company, 2005.

CUTRER, L. M. Time and tense in narrative and in everyday language. 1994. University of California, 1994.

DEMŠAR, J. et al. Orange: Data Mining Toolbox in Python Tomaž Curk Matija Polajnar Laň Zagar. Journal of Machine Learning Research, v. 14, p. 2349-2353, 2013.

DOWTY, D. R. Word meaning and montague grammar. Amsterdam: Springer, 1979. Disponível em: http://www.springerlink.com/index/10.1007/978-94-009-9473-7_1.

EDWARDS, D. Narrative: stories and rememberings. Discourse and cognition. Trowbridge: Redwood Brooks, 1997. p. 263-294.

FLEISCHMAN, S. Tense and narrativity: from medieval performance to modern fiction. London: Routledge London, 1990.

FONSECA, A. M. H. DA. Tempo, Aspecto, Modo / Modalidade (TAM) na expressão de futuridade. Estudos Linguísticos, v. 39, n. 1, p. 45-58, 2010. Disponível em: http:// www.gel.hospedagemdesites.ws/estudoslinguisticos/volumes/39/v2/EL_V39N1_04. pdf. Acesso em: 31 jul. 2019.

HOPPER, P. J.; THOMPSON, S. A. Transitivity in grammar and discourse. Language, v. 56, n. 2, p. 251, jun. 1980. Disponível em: https://www.jstor.org/ stable $/ 413757$ ? origin $=$ crossref.

LABOV, W. Alguns passos iniciais na análise da narrativa. Trad. de Waldemar Ferreira Netto. The Journal of Narrative and Life History, v. 7, p. 1-18, 1997.

LABOV, W.; WALETZKY, J. Narrative analysis. Oral versions of personal experience. Seattle and London: University of Washington Press, 1967.p. 12-44.

LANGACKER, R. W. Foundations of cognitive grammar. Stanford: Stanford University Press, 1987. v. I.

LÓPEZ-ORTEGA, N. R. Tense, aspect, and narrative structure in Spanish as a Second Language. Hispania, v. 83, n. 3, p. 488-502, 2000.

MITTMANN, M. Análise da estruturação de diálogos e monólogos na fala informal: quantificando as diferenças - s. Domínios de Lingu@gem, v. 7, n. 2, p. 338-372, 2013.

MITTMANN, M. M.; RASO, T. The The C-ORAL-BRASIL informationally tagged mini-corpus. In: MELLO, H.; PANUNZI, A.; RASO, T. (Org.). . Pragmatics and prosody: illocution, modality, attitude, information patterning and speech annotation. Firenze: Firenze University Press, 2011. p. 151-183. 
OUYANG, J.; MCKEOWN, K. K. Towards automatic detection of narrative structure. European Languages Resources Association (ELRA), Reykjavik, Iceland, p. 4624-4631, 2014. Disponível em: http://www.lrec-conf.org/proceedings/lrec2014/pdf/1154_ Paper.pdf.

PROPP, V. Morphology of the Folktale. Tradução Laurence Scott. 2nd. ed. Austin: University of Texas Press, 1968.

RASO, T.; MELLO, H. The C-ORAL-BRASIL I: Reference Corpus for Informal Spoken Brazilian Portuguese. Belo Horizonte: Editora UFMG, 2012. v. 1.p. 362-367. Disponível em: <http://link.springer.com/10.1007/978-3-642-28885-2_40>.

RÜHLEMANN, C. Narrative in English conversation. Cambridge/New York: Cambridge University Press, 2013.

SILVA-CORVALÁN, C. Linguistic Society of America Tense and Aspect in Oral Spanish Narrative: Context and Meaning. Language, v. 59, n. 4, p. 760-780, 1983. Disponível em: https://www.jstor.org/stable/413372.

SULLIVAN, W. J.; BOGDAN, D. R. Tense, aspect and the organization of Polish narrative. Word, v. 52, n. 3, p. 357-368, 2001.

TENSE AND ASPECT. In: HAMM, Friedrich; BOTT, Oliver. (E. N. Zalta, Org.) The Stanford Encyclopedia of Philosophy. Fall 2018 ed. [S.1.]: Metaphysics Research Lab, Stanford University, 2018. Disponível em: https://plato.stanford.edu/entries/tenseaspect/. Acesso em: 30 jul. 2019.

TRAVAGLIA, L. C. O aspecto verbal no português: a categoria e sua expressão. Uberlândia: Universidade Federal de Uberlândia, 1981. Disponível em: https://catalogobiblioteca. ufmg.br/pergamum/biblioteca/index.php. Acesso em: 30 jul. 2019.

TURNER, M. The Literary Mind. New York/Oxford: Oxford University Press, 1996. VENDLER, Z. Verbs and Times. The philosophical review, v. 66, n. 2, p. 143-160, 1957. 